\title{
TOWARD AN EMPATHETIC UNDERSTANDING OF SCHOLARSHIP
}

\author{
DANA CHRISTINE COX \\ Miami University
}

ABSTRACT

In this paper I take an autobiographical stance on knowledge production in the field of Mathematics Education, acknowledging forms of academic and racial privilege. I use my experiences as a backdrop by which to project a more empathetic approach to scholarship in mathematics education. Using the framework of rough draft thinking (JANSEN et al., 2017 ), I expose the contradictions in what we believe to be true about the acquisition and generation of mathematical and pedagogical knowledge, and the structures of scholarship in mathematics education. I make three recommendations: 1 . address the need for rough draft spaces within the existing structure of academia; 2 . we should reimagine our roles within the peer-review system; and 3. we need to adopt more empathetic methodologies that allow human voices to be centered in our scholarship without reduction or interpretation. It is no longer acceptable to believe that the gaze and interpretation of an objective researcher is as valid as the first-hand perspective of participants.

Keywords: Methodology. Empathy. Classroom-Based Research.

\section{RESUMO RUMO A UMA COMPREENSÃO EMPÁTICA DA BOLSA DE ESTUDOS}

Neste artigo, tomo uma postura autobiográfica sobre a produção de conhecimento no campo da Educação Matemática, reconhecendo formas de privilégio acadêmico e racial. Utilizo as minhas experiências como pano de fundo para projetar uma abordagem mais empática da bolsa de estudos em educação matemática. Utilizando a estrutura do pensamento preliminar (JANSEN et al, 2015), expus as contradições no que acreditamos ser verdade sobre a aquisição e a geração de conhecimentos matemáticos e pedagógicos, e as estruturas do conhecimento acadêmico em educação matemática. Eu faço três recomendações: 1 . abordar a necessidade de rascunhos na estrutura acadêmica existente; 2 . devemos reimaginar nossos papéis dentro do sistema de revisão por pares; e 3. precisamos adotar metodologias mais empáticas que permitam que as vozes humanas 
sejam centradas em nossa pesquisa, sem redução ou interpretação. Não é mais aceitável acreditar que o olhar e a interpretação de um pesquisador objetivo são tão válidos quanto a perspectiva em primeira mão dos participantes.

Palavras-chave: Metodologia. Empatia. Pesquisa baseada em sala de aula.

\section{RESUMEN HACIA UNA COMPRENSIÓN EMPÁTICA DE LA BECA}

En este artículo, tomo una postura autobiográfica sobre la producción de conocimiento en el campo de la Educación Matemática, reconociendo formas de privilegio académico y racial. Utilizo mis experiencias como telón de fondo para diseñar un enfoque más empático de la beca en educación matemática. El uso de la estructura del pensamiento preliminar (JANSEN et al., 2015), expuso las contradicciones en lo que creemos que es verdad sobre la adquisición y generación de conocimientos matemáticos y pedagógicos, y las estructuras del conocimiento académico en educación matemática. Yo hago tres recomendaciones: 1. abordar la necesidad de borradores en la estructura académica existente; 2 . debemos reimaginar nuestros papeles dentro del sistema de revisión por pares; y 3. necesitamos adoptar metodologías más empáticas que permitan que las voces humanas sean centradas en nuestra investigación sin reducción o interpretación. No es más aceptable creer que la mirada y la interpretación de un investigador objetivo son tan válidas como la perspectiva de primera mano de los participantes.

Palabras Clave: Metodología. Empatía. Investigación basada em el aula.

On the day that I defended my dissertation, my mother photographed me in my office. My eyes are squeezed shut and my smile is openmouthed and full. My arms are raised in victory and I am pointing upward. The emotion in the photograph is as real as the silliness. Pointing upward means many things to different people, but in this case I was imagining my fingers like roman candles shooting fireworks into the sky. My good friend Amy and I use this form of celebration as a way to represent an explosion of joy and excitement that is just too large to contain in our bodies. I believe that scholarship can feel like this.
My dissertation advisors at Western Michigan University also believed that scholarship could be exciting and that the emotions associated with that excitement should be shared openly among colleagues. I loved being in their offices and, after sometimes shedding tears of insecurity, frustration or failure, usually left with a more subdued version of that excitement (and a long to-do list.) I know this is not always the case for PhD students (SCHLOSSER et al, 2003). I consider this an element of privilege that I carry and continue to enjoy today, more than ten years later. Taking a closer look, I acknowledge that generosity and the privi- 
lege of being able to be in someone else's office space talking over and thinking through ideas I called my own.

This was offered to me in an automatic way. I use the term automatic to mean that it was a component of my work and time in graduate school that I could (and did at the time) take for granted. The automaticity is another aspect of my privilege. I know that many graduate students are dissatisfied or anxious about the access they have to advisors and the degree to which they provide direction (FAGEN; SUEDKAMP WELLS, 2004; NYQUIST; WOODFORD, 2000). My relationship with my advisors led me to expect that all aspects of scholarship should be conducted openly, even if it is not entirely collaborative. This expectation sat alongside my belief that scholarship could be rewarding and exciting. They were deeply rooted in me as I set off along the tenure-track in the United States.

\section{Space for Rough Draft Talk}

After graduate school, I found collaborative colleagues and rewarding scholarship at Miami University. These collaborations and friendships only deepened the beliefs I brought with me from graduate school and I continued my privileged status. There, we created space to be unsure and to engage in what Jansen et al. (2017) refer to as Rough Draft Talk. While Jansen et al. (2017) are referring to mathematical thinking and spaces, there is a parallel when it comes to mathematics education scholarship. They claim that in order to support rough draft talk in an academic community, we should engage three principles, which I am interpreting to fit a community of mathematics education scholarship.

1. We should foster a culture tolerant of intellectual risk taking and allow for failure as a natural occurrence.
2. We should frame scholarship as a longitudinal process where time and revision are necessary.

3. We should expand what counts as a valuable contribution and seek to raise the status of contributing scholars.

The current culture of mathematics education scholarship includes very few spaces where all three of these principles are brought to bear and where rough draft thinking is valued. In the following sections, I will share some personal experiences and project ways that we as a scholarly community might better enact these three principles.

\section{A Culture of Risk and Failure}

Consider the avenues that are traditionally available to scholars for sharing their work. Attending professional conferences is surely time to engage with others about your ideas, but the work that makes it into the program is expected to be finished and any official time given to discussion is usually focused on the implications of the work or connections to other studies. Other outlets for scholarship also perpetuate the notion that academic work is polished, finished, and frozen. What we read in journals, books, and proceedings is not (always) an open invitation to debate and, more to my point here, cannot be altered or changed by those who read it.

Scholars do often create rough draft spaces at conferences outside of the presentation room. While I served on the Program Committee for the Association of Mathematics Teacher Educators (AMTE), we received many requests for space to hold meetings for research groups, mentoring groups, and even support groups. At the 2018 and 2019 conferences, we made a commitment to address this need as an organization. Extensive space was purchased and set aside as informal and unscheduled so that groups of scholars would have a place to 
have these working conversations in a face-toface format. However, this comes at a cost to program participation as these simultaneous meetings pull people out of the formal and scheduled presentations. In my experience, giving a prepared talk to two people can be annoying or even demoralizing. Furthermore, the spaces were public and not suited to more personal collaborations.

Physical spaces where rough draft talk is possible can be created outside of mainstream academic venues, but come at a cost for scholars. I will share an example here. For ten years, I set aside one week per summer to retreat into the granite cliffs of West Virginia to a cabin with no phone service and spotty internet to commune with other female scholars and to sit with them in silence as we each think our rough draft thoughts. We shared tight quarters in a small cottage, cooked communal meals, and played competitive board games after dinner. "Women's Writing Week", as we call it, is another source of privilege for me. I am a wife and mother and so it requires a partner to take over when my parenting stops. It requires personal funding, as my institution does not provide travel funds without an accompanying by-line on my vita. It also requires the careful cultivation of a trusted network of colleagues, something that came automatically in graduate school, luckily at my current university, but intentionally among these women.

After two summers of intense work, we saw the value in opening up this opportunity to other female scholars who would want to participate, but needed financial or institutional support. We wrote a conference proposal to support the work, but were denied. One reviewer wanted more specificity with regard to what would be produced. Another reviewer suggested that women no longer needed separate spaces from men, having achieved complete equality in academia and that to offer this space exclusively to women was problematic. We gave up on the institutional support for this work, but we did notice other groups of female scholars in our social networks planning their own small retreats elsewhere.

At our version of Women's Writing Week, we listen to each other's half-baked arguments with methodological belief (ELBOW, 2008). Sharing expertise sounds tentative and exploratory, "Have you read this person's work?" or "I remember reading something out there that sounds like that." This is a different tone that we take; working alongside one another on parallel projects. It is different from those meetings we have with co-PIs or co-authors who are as immersed and invested in a project as we are. This is an implicit agreement to take up one another's ideas without staking claim in the output.

We also go beyond academic thinking and provide emotional and academic support to one another during a process that can be fraught with strong feelings both positive and negative. It is common for someone to "need a long walk" after a particularly challenging discussion. This time away to mull over feelings, thoughts, and ideas is a powerful way to open our minds to and confront living contradictions (WHITEHEAD, 1989) in our work as mathematics educators (COX et al., 2014). Suggesting alternate publication venues, setting deadline reminders, sharing experiential knowledge of the publishing or tenure process, and empathizing with one another about the human challenges of being an academic are also ways that we raise one another up for success.

I'll speak to my own feelings about the human challenges of being an academic here and tell you honestly that when I write, I experience self-doubt as I wonder if what I'm thinking will be found important, useful, or interesting to others. I feel anger and sadness as I read or hear critique that has clearly misunderstood 
my point or identified a weak spot. I feel guilt during periods of success, that somehow I am taking opportunities away from others or crowding the room. Unlike in graduate school, where my advisors celebrated each victory, it can be hard for me to talk to others about what is going well in my scholarly life. I feel extreme joy when I reread a passage and find it resonates just as much as when I wrote it. I feel pride. I feel confusion. I feel fulfilled. I don't feel fulfilled.

Writing is emotional work. Working with and supporting other writers requires an empathetic stance where minds remain open to possibility and hearts vulnerable and open to others. This is different from sympathy, which is the recognition that we have feelings in common. An empathetic stance is a position where you take up, understand, and share the feelings and ideas of another. It requires rough draft spaces where hearts and minds can be heard and changed-especially our own. The costs associated with sharing this space with colleagues was well-worth what I received in return, however I acknowledge that the costs are high and that we, as a field, would benefit from taking on the responsibility of creating more of these spaces for every scholar. I challenge us to consider how we could include them at large professional conferences and meetings while also reducing the impact on other forms of participation. Mathematics educators love a good optimization problem!

\section{Writing as a Longitudinal Process}

Our typical published products such as scheduled presentations and conference papers are the result of a strong system of blind peer review. Some may argue that our current emphasis on blind peer review is an example of a rough draft space. It is true that it is a mechanism that supports longitudinal work via revision and often leads to improved scholarship over time. However, it fails to meet Jansen et al.'s (2017) first principle as it is a conservative system that does not always value risk-taking and failure and it doesn't always feel very safe. There isn't always a revise and resubmit option, making rejection feel, in part, like a permanent failure.

This is, in part, due to the scientific community's reliance on methodological doubt (ELBOW, 2008). Methodological doubt is akin to critical thinking and honored in our academic worlds. When we listen or read with doubt, we identify weakness. Some measure of this practice is useful in the peer review process. The process of peer review is predicated on a reader who questions and evaluates the merit of the written work. However, Elbow (2008) contrasts this with another type of listening which he refers to as playing the believing game. In this way of listening, we read to find the truth and merit in the presented ideas. Elbow describes it as "trying to be as welcoming or accepting as possible to every idea we encounter...actually trying to believe them," (p.2).

My first exposure to the Believing Game was in the context of mathematics teaching (HARKNESS, 2009). I am grateful to Harkness' vulnerability in sharing what it meant to play the game with learners of mathematics. Practicing methodological believing in the classroom is related to another construct, mathematical empathy. Araki (2015), building on the notion of empathy as seeking to understand another through their frame of reference, defines mathematical empathy as "the ability to comprehend another person's ideas and the true meaning or purpose behind them, seeking to utilize the other person's frame of reference," (p. 118). If teachers are intended to elevate student thinking within mathematics instruction, then mathematical empathy is required. Mathematical empathy is what allows us to play the believing game and find the truth in the math- 
ematics that students share. I am grateful for Araki's work as well as Harkness' vulnerability.

Recontextualizing this practice, we imagine a different structure and purpose for peer review, one that takes a more longitudinal approach to scholarship and dissemination that is supportive of risk-taking. If we reimagine submitting your work as entering a rough draft space, then the work of the reviewer shifts and so does our interpretation of their findings. I believe this to be more than just a shifting mindset and more of a direct shift in goals for the work. Reviewers, in this sense, play the believing game as co-conspirators, working alongside authors to find the truth in the work. In my work as a reviewer, I try to write each and every review and decision letter as if I was sincerely trying to push that paper toward acceptance. Even if I'm recommending that the author write an entirely new paper, I'm still working from the assumption that presented ideas are worthy of publication. What if we, as a field, were to reimagine reviewers as mysterious hidden co-conspirators, working alongside authors to help move written work to a more final stage? Doing this work and assuming a co-conspirator role, requires an empathetic stance. We must be willing to take up and understand someone else's ideas or context for just a while, understanding its value from the perspective of the author, and taking no future stake in the work for ourselves.

\section{Widening our Window}

The peer-review process also provides a very narrow window for what counts as a valuable contribution and risk is not often rewarded. The trustworthiness and scientific validity of a study is often found in a comparison of one truth to another. If a study takes an oppositional perspective or provides evidence other than what we'd expect it to be based on what has come before, it is often deemed less trustworthy. Stephens-Davidowitz's (2017) study on the impact of racism on the election of Barack Obama provides an example of this. Stephens-Davidowitz used Google Trends data to show that even though Barrack Obama won the U.S. presidential election in 2008, he lost roughly 4 percentage points nationwide on the basis of explicit racism. This finding becomes increasingly relevant and believable in the wake of the 2016 U.S. presidential election. He believes that these findings were repeatedly rejected for peer-reviewed publication because,

"it was impossible to believe that so many Americans harbored such vicious racism. This simply did not fit what people had been saying. Besides, Google searches seemed like such a bizarre dataset," (p. 9).

In this case, the presentation of an alternate methodology created suspicion in the minds of the reviewers which may have prevented these ideas from being valued and even published. The added layer of having results that contradicted a desired result and commonly held beliefs was not insignificant here, either.

These methodological exclusions make it difficult for mathematics education studies that utilize alternative methodologies such as narrative inquiry (CLANDININ \& CONNELLY, 2000), self-study (LaBOSKEY, 2004), or autoethnography (ELLIS \& BOCHNER, 2000) to find outlets for dissemination. I do work that strives to open that window for classroom teachers. I want my scholarship to be inclusive of teachers not just as participants, but as knowledge generators (D'AMBROSIO; COX, 2015b) and strive to give them agency in the field of educational research. In this way, I have tried to use my position and power to make room for other voices and have refused to generalize, interpret, or objectify any of the work to which they have given me access. To that effort, I have experienced a tighter methodological window. I have 
experienced criticism from reviewers on a narrative inquiry study claiming that narrative inquiry is not scientific research because it is not empirical or evaluative, "no research questions are stated or investigated in the paper, and the paper presents no empirical data on the possible effects on students' learning." Methodological concerns, as in the following quote, serve to limit what counts as a valuable contribution to the field, excluding the important voices of teachers and students.

"I have concerns about the methodology. In general, I'm skeptical whenever the primary author is also the primary research subject. [...] It is extremely clear in education and psychology research that people have extremely biased views of themselves, which makes self-reflection an unsuitable process for doing social science."

Even more concerning to me, I witness how methodological concern has a racial impact while following black scholars on Twitter. It is apparent when black scholars announce exciting new grants or publications examining the experiences of black mathematicians or math students to a chorus of methodological criticism. That criticism, which often comes from white scholars, questions the validity of studies that center the voices of black scholars or identities. Martin (2013) characterizes mathematics education as a white institutional space and our collective sense of validity is based on the assumption that knowledge generation is neutral and disconnected from race. Saving the "valid scientific research" designation for those studies that utilize existing methods, are grounded in existing theories, or whose findings fit with expected patterns is a way to tighten the window and control what is considered knowledge and who gets to generate it. I am a white scholar and am privileged because my work, even in this paper, comes with a white perspective which I acknowledge and own. I do not face the same racial and epistemological obstacles as scholars of color, even if we may have some methodological obstacles in common.

According to Ubiratan D'Ambrosio (2015), embracing new knowledge generators could allow us to break away from our existing "epistemological cages", which would implicate our current perceptions of expertise within our field and open the door to consider how white supremacy and power in general permeate status in our field. Wagner (1993) presents an alternative measure of epistemological worth, suggesting "we'd be better off evaluating the value and meaning of a study based on how far beyond ignorance this work takes us ( $p$. 16) as opposed to how closely something mirrors a perceived reality. In this way, we open ourselves up to studies that expose our blind spots as well as those that exist to fill in our known blanks. This would make room for more empathetic methodologies.

\section{Empathetic Methodologies}

I have invoked empathy as a means to fully realize each of the three principles above. To foster a culture of risk and failure, we need to create more empathetic spaces where we take up work alongside others and also make them more accessible to all scholars. To make knowledge production more longitudinal, we need to find a way to practice methodological belief and take an empathetic stance as reviewers. To widen the window of knowledge generation, we need more empathetic methodologies. In this section I will focus on developing what I mean by empathetic methodologies and collaboration with teachers.

\section{Learning to Collaborate}

While my advisors were encouraging and supportive in my writing process, writing with others was not something that I learned to do in graduate school. Collaborative writing was 
seen as putting together a puzzle of individual pieces and sounded clinical and efficient, "You write the history prior to Sputnik and I'll pick it up in 1957". In order to be seen as a competent and effective collaborator, I sometimes took on more or more ambitious work than I wanted and tempered my anxiety, confusion and frustration when talking with some colleagues. It wasn't until I arrived at Miami University that I found myself able to put down the mask of competence and be vulnerable with collaborators. Once I did, though, I opened a floodgate of ideas that energized me and gave me purpose that was continually renewed.

I also needed to learn to collaborate with teachers. As a faculty member at a university, I needed the help and participation of local teachers and administrators in my pursuit of classroom-based scholarship projects. Working on a Mathematics Science Partnership (MSP) grant was one experience that helped me understand the difference between working with teachers and collaborating.

\section{Project DOVETAIL}

In the course of working on an MSP grant that we called Project DOVETAIL, my colleagues at Miami and I planned a yearlong Leadership Academy that fit under the "train the trainers" model for professional development. DOVETAIL stood for Developing Ownership and Vision: Empowering Teachers as Instructional Leaders. With current demands for professional development programs that will reach large numbers of teachers, the idea of teachers themselves participating in the professional development of their colleagues is appealing to the mathematics education community. Koellner, Jacobs, and Borko (2011) call for the purposeful preparation of a cadre of leaders who can implement effective high-quality Professional Development. My colleagues and I have found (in our exploration of other teacher leadership development projects) a predominance of a design principle where teacher leaders experience, as learners, the PD that they will provide to others.

One of the recommendations when doing this work with teachers is adapting PD to support local goals and interests. That's not easy when you have to write a full grant proposal complete with designed curriculum before you even get to solicit your participants. We were doomed to begin. At this same time, Martin (2013) was writing about the need to more effectively partner with teachers to uncover and understand how they are positioned by political forces. This was an excellent case. External funding is often required by school districts considering curricular or instructional reforms, but the funding cycle often works to suppress teachers' voices and needs in the chaos of policy-driven reform.

This theory about the development of teacher leaders produces leaders who exemplify expertise, who stand apart from other teachers whom they call colleagues, and who take on a separate role as "leader" that may include duties such as facilitating district professional development, coaching, classroom observation and peer review of teaching. I have used the metaphor of "Playing Telephone" to describe it elsewhere (D'AMBROSIO; COX, 2015b). We were shocked mid-way through when teachers who had been happy to participate in our curricular activity balked at the thought of identifying as teacher leaders. One first-grade teacher wrote, "I am not sure that I really want to become a teacher leader...just because you try something doesn't make you an expert and teachers may be afraid of being perceived as representing themselves in that way."

In this moment, we confronted a living contradiction (WHITEHEAD, 1989) in our assumptions and stance. At all times, we believed that teachers deserved agency and voice and 
intended to empower them as mathematics education leaders. However, the game of telephone (where secret messages are whispered from one person to another around a circle) positioned teachers as message receivers and emerging experts (a designation that university faculty got to bestow) and denied teachers the very things we had intended the program to develop.

This story (the one I struggle to tell) centers on the impact of that realization on the relationships in our community. Another teacher wrote this passage, showing extreme empathy for her fellow leaders, but also all of the other teachers trying things, studying things, and working their practice without our help. She's responding to a presentation from two leaders on something they tried, revised, and tried again in the previous month.

"As I watched the presentation given by two teachers today, I thought of all the teachers in the district who have done similar things for much longer than twice and somehow putting people and ideas in front of others is in some way suggesting that they are experts. Could this be why no one wants to be watched teaching? Just because you try something doesn't make you an expert and teachers may be afraid of being perceived as representing themselves in that way. We are always trying new things and how many of our new ideas really stand the test of time."

In this same time period, in a small group meeting, another teacher expressed a new vision of what leadership might entail. She later wrote, "I don't want to be a part of a group of leaders. I want to be a part of a leadership group." To unpack this statement as a unified group and eventually negotiate what leadership would mean to us would mean redefining leadership and constructing a new purpose for our MSP project. We gave up control of direction and relinquished our oversight over the project. We became collaborators and re- search participants alongside our teachers. It is in that decision that we moved away from working with teachers to collaboration.

These kind of mid-stream programmatic changes are violent under the current funding model. It is a model used by the United States National Science Foundation, too, that prizes well-designed research and evaluation studies prior to funding, which means prior to meeting with teachers. It also prizes articulated goals and promises that you'd adhere to them-or risk losing your funding. This model is not designed to create empathetic spaces for research, nor spaces for rough draft thinking. It's teaching and research that acts like a proposed drug or treatment -crystallized and polished before it even begins.

Opening up an empathetic space, and choosing teachers over research design is an act of Creative Insubordination (D'AMBROSIO \& LOPES, 2015; LOPES \& D'AMBROSIO, 2015). In order to commit this act of insubordination along with my collaborators, I needed privilege. I benefited from collegial support-it was an unanimous vote in favor of insubordination and there is power in numbers. We then experienced an increased sense of urgency in exploring alternative methodologies by which to tell our important story. With some experience with self-study (COX et al., 2014), we began learning all that we could about Narrative Inquiry and autobiographical work. A remarkable set of Brazilian scholars operating on the boundary of methodological knowledge were visiting our university at the time and we voraciously read all that they brought to us.

By challenging conceptions of expertise and expanding the window of knowledge generation, our PD became based on the realities of the classroom and occurred naturally in the course of investigating classroom practice in small supportive partnerships. This learning was rigorous, supported discussion of content 
and pedagogy, and had an immediate effect on classroom activity. Ultimately, what we learned is that it is not a matter of trusting that teachers will be productive with neither assigned direction nor oversight. It is the act of not even questioning them that ensures both agency and voice.

At the end of year one, after closing the first annual Summer Institute planned and run entirely by district teachers and attended by university partners, we were confronted with the task of writing about the work. We had some questions.

1. How do we find meaning in educational research on teaching?

2. Who is in control of the research design and who gets to participate?

3. How should we collect and analyze data?

4. For what purpose do we disseminate our work?

We were in search of new ways to tell important stories. It caused us to write about an idea, something new and not yet available: Empathetic Methodologies (D'AMBROSIO; COX, 2015a). This publication wasn't a polished, finished, final paper that contained answers. It was questioning. It invited response. It promised that it was malleable, flexible, and in progress. It was a plea to the field to help us with these questions. We were looking for methodologies that stem from a place of methodological belief that are aimed at helping the researcher understand more from the perspective of teachers and to understand themselves in relation.

Beyond acknowledging researcher bias, we were moving to a place of empathy where the researcher steps through their lens into the world of the participant where it is not our place to find meaning, but to accept the meaning presented to us. The collaborative work on this paper was some of the deepest thinking and personally-challenging work I have ever done in my life. It was also facilitated by Google Docs and and chat windows as writing often happens late at night in pajamas when neither of you can sleep. I am grateful for the time I had with Beatriz D'Ambrosio and our $1 \mathrm{am}$ inspiration sessions are some of my fondest academic memories.

\section{Conclusion}

In this paper, I have used the backdrop of my academic experiences as a lens through which to examine a more empathetic approach to scholarship in mathematics education. Using the framework of rough draft thinking (JANSEN et al., 2017), I have exposed a contradiction in what we believe to be true about the acquisition and generation of knowledge between the contexts of mathematics teaching and mathematics education scholarship. If we believe that knowledge is generated in 1) a culture that supports risk-taking and failure; 2) takes a longitudinal perspective on learning; and 3 ) Widens the window of knowledge generation, then we should incorporate these principles in our work as scholars. This will require us to turn our critical gaze inward and consider ways that existing structures work against these principles.

I have made three recommendations. First, we should address the need for rough draft spaces within the existing structure of academia. These spaces should be accessible to all and not just reserved for those with the financial, social, and institutional capital to participate. This may include a review of existing tenure systems, a topic I have not addressed here, but feels as urgent as any other. Second, we should reimagine our roles within the peer-review system. We should not just act as knowledge gate-keepers or bouncers, but also as co-conspirators and allies. We need to im- 
plement review criteria that would allow us to accept papers that expose ignorance and not just confirm what we believe to be true. Third, we need to adopt more empathetic methodologies that allow human voices to be centered in our scholarship without reduction or interpretation. It is no longer acceptable to believe that the gaze and interpretation of an objective researcher is as valid as the first-hand perspective of participants.

\section{References}

COX, D. C. Repositioning Ourselves: Acknowledging contradiction. Bolema: Boletim de Educação Matemática, Rio Claro, SP, v. 28, n. 49, p. 990-1011, ago. 2014.

CLANDININ, J.; CONNELLY, M. Narrative Inquiry: Experience and story in qualitative research. California: Jossey-Bass, 2000.

D'AMBROSIO, U. From Mathematics Education and Society to Mathematics Education and a sustainable civilization: a threat, an appeal, and a proposal. In: MUKHOPADHYAY, S.; GREER, B. (Eds.). PROCEEDINGS OF THE EIGHTH INTERNATIONAL MATHEMATICS EDUCATION AND SOCIETY CONFERENCE, 8., 2015, Portland (OR). Anais... Portland (OR): Ooligan Press; Portland State University, 2015. p. 19-30.

D'AMBROSIO, B. S.; COX, D. C. An Examination of Current Methodologies in Mathematics Education Through the Lenses of Purpose, Participation, and Privilege. Revista Perspectivas da Educação Matemática, v. 8, n. 18, p. 687-708, ago. 2015a.

D'AMBROSIO, B. S.; COX, D. C. Learning to Lead. In: BARTELL, T. G., BIEDA, K. N., PUTNAM, R. T., BRADFIELD, K.; DOMINGUEZ, H. (Eds.). Proceedings of the 37th annual meeting of the North American Chapter of the International Group for the Psychology of Mathematics Education. East Lansing, MI: Michigan State University, 2015b. p. 640-646.

D'AMBROSIO, B. S.; LOPES, C. E. Creative Insubordination: an invitation to reinvent the mathematics educator. Bolema: Boletim de Educação Matemáti- ca, v. 29, n. 51, p. 1-17, 2015.

ELBOW, P. The believing game or methodological believing. JAEPL: The Journal of the Assembly for Expanded Perspectives on Learning, v. 14, p. 1-11, Winter 2008-2009.

ELLIS, C.; BOCHNER A. P. Autoethnography, personal narrative, reflexivity: Researcher as subject. In: DENZIN, K.; LINCOLN, Y. S. (Eds.). Handbook of qualitative research. Thousand Oaks, CA: Sage Publications, 2000. p. 733-768.

FAGEN, A. P.; SUEDKAMP WELLS, K. M. The 2000 national doctoral program survey: An on-line study of students' voices. In: WULFF D. H.; AUSTIN, A. E. (Eds.). Paths to the professoriate: Strategies for enriching the preparation of future faculty. San Francisco, CA: Jossey-Bass, 2004. p. 74-91.

HARKNESS, S. S. Social constructivism and the Believing Game: a mathematics teacher's practice and its implications. Educational Studies in Mathematics, v. 70, n. 3, p. 243-258, 2009.

JANSEN, A., COOPER, B., VASCELLARO, S.; WANDLESS, P. Rough-Draft Talk in Mathematics Classrooms. Mathematics Teaching in the Middle School, v. 22, n. 5, p. 304-307, 2017.

LaBOSKEY, V. K. The methodology of self-study and its theoretical underpinnings. In: LOUGHRAN, J.; HAMILTON, M. L.; LaBOSKY, V. K.; RUSSELL T. (Eds.). International handbook of self-study of teaching and teacher education practices. Dordrecht, The Netherlands: Springer, 2004. p. 817-869.

LOPES, C. E.; D'AMBROSIO, B. S. Professional development shaping teacher agency and creative insubordination. Ciência \& Educação, Bauru, v. 22, n. 4, p. 1085-1095, 2016.

MARTIN, D. B. Race, racial projects, and mathematics education. Journal for Research in Mathematics Education, v. 44, n. 1, p. 316-333, 2013.

KOELLNER, K; JACOBS, J.; BORKO, H. Mathematics Professional Development: Critical Features for Developing Leadership Skills and Building Teachers' Capacity. Mathematics teacher education and development, v. 13, n. 1, p. 115-136, 2011. 
SCHLOSSER, L. Z.; KNOX, S.; MOSKOVITZ, A. R.; HILL, C. E. A qualitative examination of graduate advising relationships: The advisee perspective. Journal of Counseling Psychology, v. 50, n. 2, p. 178-192, 2003.

STEPHENS-DAVIDOWITZ, S. Everybody lies: Big data, new data, and what the internet can tell us about who we really are. New York: Harper Collins, 2017.

WAGNER, J. Ignorance in educational research or, how can you not know that? Educational Researcher, v. 22, n. 5, p. 15-23, 1993.

WHITEHEAD, J. Creating a living educational theory from questions of the kind, "How do I improve my practice?". Cambridge Journal of Education, Cambridge, v. 19, n. 1, p. 41-52, 1989.

Recebido em: 03.02.2019 Aprovado em: 30.03.2019.

Dana Christine Cox Associate Professor of Mathematics Education in the Department of Miami University. E-mail: Dana.Cox@miamioh.edu

Department of Mathematics, 301 S. Patterson Ave. 45056 Oxford, OH - USA

Phone: 513-529-9728 